\title{
Carriage of potentially fish-pathogenic bacteria in Sparus aurata cultured in Mediterranean fish farms
}

\author{
M. J. Pujalte ${ }^{1,2}$, A. Sitjà-Bobadilla ${ }^{3}$, P. Álvarez-Pellitero ${ }^{3}$, E. Garay ${ }^{1,2, *}$ \\ ${ }^{1}$ Instituto Cavanilles de Biodiversidad y Biología Evolutiva, and ${ }^{2}$ Departament de Microbiología i Ecología, \\ Facultad de Biologia, Campus de Burjassot, Universitat de València, 46100 Valencia, Spain \\ ${ }^{3}$ Instituto de Acuicultura de Torre de la Sal, Consejo Superior de Investigaciones Científicas (CSIC), Torre La Sal, \\ Ribera de Cabanes, 12595 Castellón, Spain
}

\begin{abstract}
A bacteriological survey of gilthead sea bream Sparus aurata from different fish farms and culture systems on the Spanish Mediterranean coast was conducted. Three different studies were performed. Study A included hatchery-reared larvae; Study B, periodic examination of randomly sampled growing fish; and Study C, growing fish sampled only during mortality/morbidity events. In Studies B and C, sea cages, earth ponds and indoor tanks were surveyed, and in both cases diseased (showing clinical signs) and non-diseased fish were included. In Study A, a shift from Vibrio spp. (30 d after hatching) to oxidative species (60 d after hatching) was detected, and no mortality events were registered. The percentage of fish yielding bacterial growth were similar in Studies B and C, reaching 57.4 and $61.3 \%$, respectively. A statistically significant relationship between the bacterial carriage and the type of facility was only found in Study B, showing that fish from sea cages had a higher bacterial occurrence than fish from other facilities. A statistically significant relationship between bacterial carriage and signs of disease was found, although the pattern differed in each study. Thus, in Study B only $36.2 \%$ of fish yielding abundant bacterial growth were diseased, versus $68.0 \%$ in Study C. In total, $25.0 \%$ of the fish examined were diseased. Bacterial species composition was similar in asymptomatic and diseased fish, except for a group of $V$. ichthyoenteri-like isolates that occurred almost exclusively in asymptomatic fish. Dominant bacterial species were $V$. harveyi and $V$. splendidus, followed by $V$. ichthyoenteri-like isolates, Photobacterium damselae ssp. damselae and $V$. fisheri. Non-fermenters were less frequent but, among them, unidentified halophilic Cytophaga-Flavobacterium isolates and Pseudoalteromonas haloplanktis were the most abundant. An association of individual species with disease was not clear, which suggests the involvement of mixed infections.
\end{abstract}

KEY WORDS: Sparus aurata · Vibrio harveyi · Vibrio splendidus - Photobacterium damsela . Pseudoalteromonas haloplanktis · Vibrio ichthyoenteri · Mediterranean aquaculture

Resale or republication not permitted without written consent of the publisher

\section{INTRODUCTION}

Mediterranean aquaculture has experienced a rapid expansion in the last decade and the number of facilities dedicated to the growth of marine finfish has dramatically increased. European sea bass Dicentrarchus labrax and gilthead sea bream Sparus aurata are presently the dominant species cultured on the Spanish Mediterranean coast and are accompanied by specific disease problems related to poor on-site conditions, poor husbandry, or adverse environmental factors. Different bacterial species have been found to be associated with disease outbreaks in marine fish farms, but the pathological role of those normally inhabiting the marine environment is unclear. Such bacteria can cause problems when conditions favour their proliferation (Rodgers \& Furones 1998), thus making the differentiation between primary pathogens and opportunistic pathogens difficult. Disease outbreaks in cultured gilthead sea bream include Vibrio spp., Photobacterium damselae, Pseudomonas spp., and Flexibacter maritimus (Breuil \& Haffner 1990, Vera et al. 1991, Balebona et al. 1995, 1998b, Berthe et al. 1995, Bovo et al. 1995, Sedano et al. 1996, Domenech et al. 1997, 
Baptista et al. 1999). These species have been recovered from moribund or recently dead fish showing clinical signs. However, studies on the bacterial flora present in asymptomatic fish are scarce.

Several studies have been conducted along the Spanish Mediterranean coast to identify the main bacterial groups present in water and bivalves (Ortigosa et al. 1994a,b, Arias et al. 1999, Pujalte et al. 1999). Some of these bacteria exhibit clear seasonal variation, as Vibrio harveyi dominated with temperatures above $20^{\circ} \mathrm{C}$ and $V$. splendidus dominated at temperatures below $20^{\circ} \mathrm{C}$ (Arias et al. 1999, Pujalte et al. 1999). These and other bacterial species showing seasonal occurrence have been reported as opportunistic pathogens for sea bass and sea bream (Balebona 1998b).

In the present study, bacterial carriage in gilthead sea bream, cultured in the Spanish Mediterranean area, from larval to commercial size fish was studied. Fish samples included both diseased (with clinical signs) and asymptomatic animals. Periodic routine samplings throughout the growing period as well as special samplings, mainly coinciding with disease outbreaks, were carried out at different fish culture facilities. The aim of this study was to determine the occurrence, relative abundance and significance of the different bacterial species associated with healthy and diseased fish during their culture.

\section{MATERIALS AND METHODS}

Fish groups. The bacteriological survey was conducted for 2 yr in several aquaculture facilities along the Spanish Mediterranean coast. Samplings were carried out as follows:

Study A: Hatchery-reared larvae were sampled on Days 30 (before weaning) and 60 (after weaning) posthatch. At each sampling, 40 larvae, along with seawater from the rearing tank, were analysed. Water temperature at the hatchery was 18 to $20^{\circ} \mathrm{C}$.

Study B: A total of 397 fish were examined from 3 farms with 2 different growing systems: sea cages (Farms F1 and F2) and intensive earth ponds (Farm F3). Fish were randomly sampled just before entering the facilities, and then at 3 mo intervals until commercial size was attained. In F1 (Western Mediterranean Sea, Castellón, Spain), fish entered with an average weight of $21.6 \mathrm{~g}$ and were delivered to the market at 339.8 g. In F2 (Western Mediterranean Sea, Tarragona, Spain), fish average weight increased from 8.5 to $281.3 \mathrm{~g}$ throughout the study, whereas in F3 (Western Mediterranean Sea, Tarragona, Spain) average weight ranged from 2.1 to $414.1 \mathrm{~g}$.

Study C: A total of 150 fish from different farms were sampled when mortalities, morbidities or abnormal events were reported by fish farmers. In addition to Farms F1, F2 and F3, another sea cage farm (F4) and the facilities (intensive indoor tanks) of the Instituto de Acuicultura de Torre de la Sal (IATS), both on the Western Mediterranean coast (Castellón), were studied.

Fish in Studies B and C were reared under natural temperature and photoperiod, and disease signs and mortalities were recorded.

Sampling procedure and bacteriological analysis. Study A: At each sampling, larvae were pooled, washed and homogenised in sterile seawater with a glass homogeniser. Both larval homogenates and seawater from the rearing tank were serially diluted in sterile seawater, plated on marine agar ( $\mathrm{MA}$; Sea Agar, Scharlau Chemie), and incubated at 22 to $25^{\circ} \mathrm{C}$ for up to $10 \mathrm{~d}$. Colonies were counted, and 30 to 40 random colonies resulting from the highest dilution were isolated and identified according to the methods described below.

Study B: At each sampling, 20 randomly collected live fish were killed by overexposure to the anaesthetic MS-222 (Sigma). The fish were weighed, measured and bacteriological samples were taken aseptically with a sterile loop from the head kidney (occasionally from the liver in small fish) and streaked on MA and tryptone soya agar plus $1 \% \mathrm{NaCl}$ (TSA1) (Scharlau Chemie) plates.

Study C: The number of fish per sampling was variable, but the same procedure described for Study B was followed.

In Studies B and C, a selection of all the different types of colonies was done after the MA and TSA1 plates had been incubated at 20 to $25^{\circ} \mathrm{C}$ for 48 to $72 \mathrm{~h}$. Plates were re-incubated for up to $10 \mathrm{~d}$ and examined for growth of slow developing colonies. Growth on both media from each individual sampled was scored according to growth, as follows: $0=$ no growth, $\mathrm{T}=$ traces of growth (1 to 9 colonies); $\mathrm{A}=$ abundant growth (10 or more colonies). Fish with at least traces of growth were considered positive $(\mathrm{P})$ for bacteria $(\mathrm{P}=$ $\mathrm{T}+\mathrm{A})$.

In both studies (B and C), sampled fish included both diseased (with clinical signs) and asymptomatic (without clinical signs) individuals. However, in Study C, diseased fish were more abundant due to the nature of the samplings. When external wounds appeared in diseased fish, additional samples were taken after washing with $70 \%$ ethanol.

Water temperatures varied from 11 to $18^{\circ} \mathrm{C}$ between December and May (considered as the cold season) and from 26 to $15^{\circ} \mathrm{C}$ between June and November (considered as the warm season).

Identification: All colonies obtained from Studies A, $\mathrm{B}$ and $\mathrm{C}$ were checked for purity by repeated streaking on MA plates, and then submitted to phenotypic tests, 
in accordance with Ortigosa et al. (1994a,b), which included: determination of Gram reaction; oxidase; $\mathrm{Na}+$ requirement; luminescence; pigmentation; fermentative metabolism of glucose; arginine dihydrolase; lysine and ornithine decarboxylases; indole production; Voges-Proskauer; growth and sucrose fermentation on thiosulphate-citrate-bile-sucrose (TCBS) agar; growth at 4 and $40^{\circ} \mathrm{C}_{i}$ hydrolysis of casein; alginate and starch, and the ability to use the following substrates as sole carbon and energy sources: L-arabinose; D-xylose; D-mannose; D-cellobiose; sucrose; lactose; D-melibiose; D-sorbitol; D-gluconate; D-glucuronate; 2-ketoglutarate; 3-hydroxybutyrate and putrescin. Additional features, determined in some strains, were: cell morphology and motility in wet mounts; catalase; nitrate reduction to nitrite; gas production from glucose and use of additional sole carbon sources (up to 60).

The results obtained were compared with diagnostic tables from Bergey's manual of determinative bacteriology (Holt et al. 1994) and the appropriate sections of the Prokaryotes (Balows et al. 1992), as well as with previous studies of our group on the bacterial diversity from the same coastal area (Ortigosa et al. 1994a,b). This allowed the identification of the isolates at the genus and, in most cases, at the species level. The tentative identification of Vibrio ichthyoenteri, the only species not included in the previous references, was accomplished according to Ishimaru et al. (1996).

Conservation: All strains were maintained in semisolid marine agar tubes, as stab cultures at room temperature in the dark. Long-term conservation was achieved by suspending cells grown on MA plates in marine broth supplemented with $20 \%$ glycerol and then freezing the suspensions at $-80^{\circ} \mathrm{C}$.

Statistics. The influence of the type of facilities and the type of study on the bacterial carriage and on the presence of disease signs was statistically analysed using a chi-square test of independence (Sokal \& Rohlf 1981), with Yates' correction for continuity when necessary. The same test was used to analyse the possible association between the presence of disease signs and bacterial growth. The Fisher exact test was run when the expected values of the contingency table were very low. All the statistical analyses were performed with Sigma Stat software (C Jandel Corporation).

\section{RESULTS}

\section{Study A: larvae}

As shown in Table 1, colony forming units per gram $\left(\mathrm{cfu} \mathrm{g}^{-1}\right)$ of larvae were always 2 orders of magnitude higher than those from the surrounding water $\left(\mathrm{cfu} \mathrm{ml}^{-1}\right.$ ). Vibrio spp. were dominant in $30 \mathrm{~d}$ larvae (mainly Vibrio splendidus and $V$. fisheri). Water samples showed greater diversity and more representatives of strictly aerobic species, mainly Alteromonas macleodii, Pseudoalteromonas haloplankis and Pseudoalteromonas spp., although Vibrio spp. were also identified (mainly $V$. splendidus). The species composition of $60 \mathrm{~d}$ old larvae was markedly different from that of $30 \mathrm{~d}$ old larvae, as Vibrio spp. were not detected, and oxidative species were dominant. Again, water samples showed a greater diversity of bacteria than the larvae, although those species detected in the larvae were also generally present in the surrounding water.

Table 1. Composition of the bacterial community associated with Sparus aurata larvae and its surrounding water, at 2 different ages post hatching

\begin{tabular}{|c|c|c|}
\hline & Larvae & Water \\
\hline \multicolumn{3}{|l|}{$30 \mathrm{~d}$} \\
\hline Colony counts & $7.2 \times 10^{7} \mathrm{cfu} \mathrm{g}^{-1}$ & $8.2 \times 10^{5} \mathrm{cfu} \mathrm{ml}^{-1}$ \\
\hline No. of isolates & 33 & 45 \\
\hline \multicolumn{3}{|l|}{$\%$ of identified species: } \\
\hline Alteromonas macleodii & 0 & 17.8 \\
\hline Marinomonas vaga & 0 & 6.7 \\
\hline Pseudoalteromonas haloplanktis & 3.0 & 13.3 \\
\hline Pseudoalteromonas undina & 0 & 8.9 \\
\hline Pseudoalteromonas sp. & 0 & 4.4 \\
\hline Vibrio alginolyticus & 0 & 6.7 \\
\hline Vibrio diazotrophicus & 3.0 & 4.4 \\
\hline Vibrio fisheri & 27.3 & 2.2 \\
\hline Vibrio harveyi & 0 & 2.2 \\
\hline Vibrio pelagius & 0 & 2.2 \\
\hline Vibrio splendidus & 54.5 & 20.0 \\
\hline Vibrio tubiashii & 0 & 2.2 \\
\hline Vibrio sp. & 12.1 & 0 \\
\hline Unidentified Gram -ve & 0 & 8.9 \\
\hline \multicolumn{3}{|l|}{$60 \mathrm{~d}$} \\
\hline Colony counts & $2 \times 10^{7} \mathrm{cfu} \mathrm{g}^{-1}$ & $9.3 \times 10^{5} \mathrm{cfu} \mathrm{ml}^{-1}$ \\
\hline No. of isolates & 20 & 44 \\
\hline \multicolumn{3}{|l|}{$\%$ of identified species: } \\
\hline Cytophaga/Flavobacterium & 85.0 & 15.9 \\
\hline Marinomonas sp. & 0 & 2.3 \\
\hline Pseudoalteromonas espejiana & 15.0 & 52.3 \\
\hline Pseudoalteromonas haloplanktis & 0 & 11.4 \\
\hline Pseudoalteromonas undina & 0 & 4.5 \\
\hline Pseudoalteromonas sp. & 0 & 4.5 \\
\hline Vibrio fisheri & 0 & 2.3 \\
\hline Vibrio harveyi & 0 & 4.5 \\
\hline Unidentified Gram - ve & 0 & 2.3 \\
\hline
\end{tabular}




\section{Studies B and C: growing fish}

Influence of the fish group and type of facility

Considering the total of 547 fish from Studies B and C together, almost $60 \%$ of them yielded bacterial growth, with $25.9 \%$ showing abundant growth. This proportion was similar in both Studies B and C (Table 2), whereas the percentage of fish with abundant bacterial growth was higher in Study C.

In Study B, the type of facility was found to be associated with the bacterial carriage, as the percentage of fish with bacterial growth was significantly higher in sea cages than in earth ponds. However, this association was not found when considering only fish with abundant bacterial growth. In contrast, in Study C there was no statistical association between bacterial growth (abundant or otherwise) and the type of facility, although fish from IATS had slightly higher values (Table 2).

Relationship between bacterial growth and presence of clinical signs

The percentage of diseased fish was statistically significantly higher in Study C (40.7\%) than in Study B $(19.1 \%)$. Overall, $25.0 \%$ of the total number of fish examined were diseased (with clinical signs). In addition, in Study C there was a statistical association between the type of facilities and the presence of clinical signs, with the lowest percentage of diseased fish in earth ponds (Table 2). Also, a statistically significant association was found between bacterial carriage and the presence of disease signs, but the pattern varied depending on the type of study (Table 3 ). Thus, in Study B (routine samplings), only $36.2 \%$ of fish with abundant bacterial growth had disease signs, versus $68.8 \%$ in Study C (mortality/morbility events). In contrast, most fish with no bacterial growth showed no disease signs in both studies. When analysing the results within each type of facility, a statistically significant association between bacterial growth and clinical signs was observed in Study C only for sea cages, and in Study B for earth ponds. However, in most types of facilities, the percentages of fish with disease signs were higher among fish with abundant bacterial growth.

A high percentage of individuals with abundant bacterial growth showed no clinical signs in the routine samplings (Study B; 69.6 and $55.3 \%$ in sea cages and earth ponds, respectively), and therefore a considerable percentage of the fish carried internal bacteria without external signs of disease.

\section{Bacterial species occurrence in fish}

The different species identified from fish yielding bacterial growth in Studies B and C are listed in Table 4. Their occurrence in diseased and asymptomatic fish, as well as in the 2 established seasons, is also indicated. Vibrio spp. were dominant, mainly $V$. harveyi and $V$. splendidus, followed by a group of strains showing a close phenotypic resemblance with $V$. ichthyoenteri (V. ichthyoenteri-like isolates), Photobacterium damselae spp. damselae, $V$. fisheri. and $V$. alginolyticus. Other Vibrio spp. were seldom recovered. Some halophilic non-fermentative species were also identified in fish of these groups, including Pseudoalteromonas spp. and Cytophaga-Flavobacterium sp., followed by other species (Marinomonas spp., Alteromonas macleodii, Shewanella spp.). A few unidentified halophilic Gram-negatives (motile, yellow

Table 2. Sparus aurata. Data on gilthead sea bream from the different types of facilities and studies yielding different types of bacterial growth. $\mathrm{P}=$ positive bacterial growth; $\mathrm{A}=$ abundant bacterial growth. IATS: Instituto de Acuicultura de Torre de la Sal

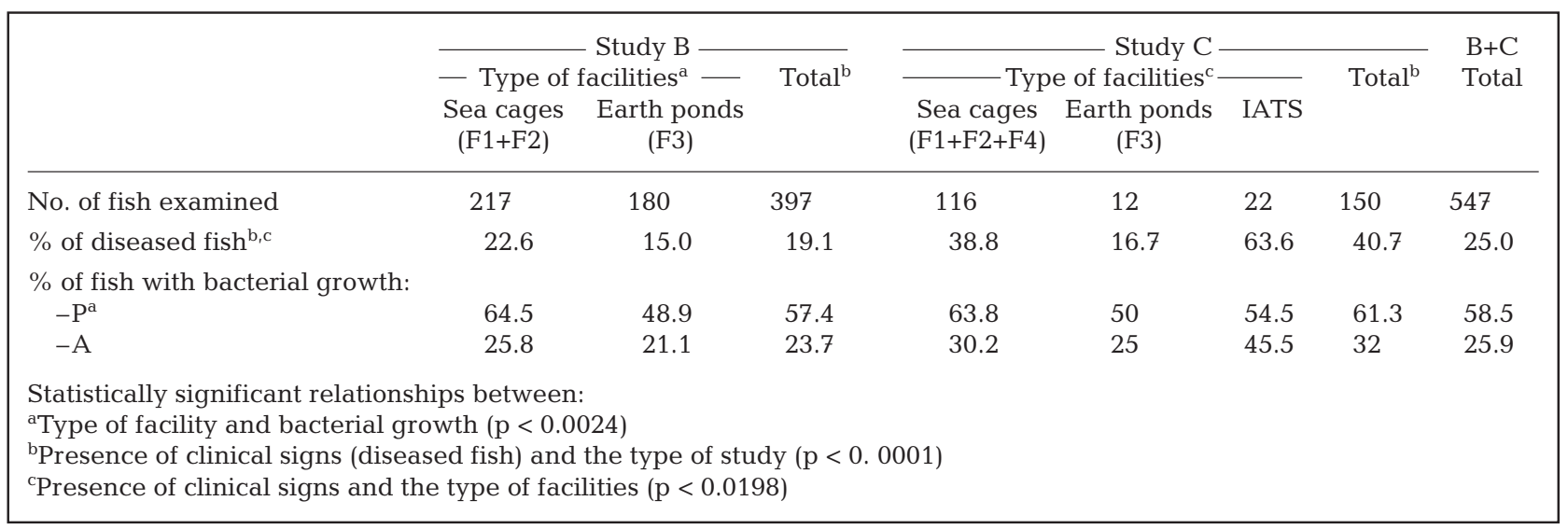


or brown-black pigmented strains) and catalase positive Gram-positives were also found. V. harveyi was the most abundant species, in both diseased and asymptomatic fish, and clearly dominated during the warm season in the studied area (temperatures above $20^{\circ} \mathrm{C}$ ). V. splendidus was the second most abundant species and showed an opposite pattern, as it was not recovered at warm temperatures. $V$. ichthyoenteri-like isolates were more frequent in asymptomatic fish, and seldom detected in diseased fish. They showed no seasonality. Photobacterium damselae ssp. damselae exhibited a moderate incidence in both diseased and asymptomatic fish, and was more abundant at warm temperatures. Although less represented, V. alginolyti- cus, and V. mediterranei and V. pelagius, also showed a seasonal occurrence, as all strains were recovered only at warm temperatures. Among the oxidative species, members of the Cytophaga-Flavobacterium group were recovered mainly at lower temperatures, and were more abundant in fish showing clinical signs. A similar prevalence was observed for Pseudoalteromonas haloplanktis.

The number of bacterial isolates per fish was variable. In the group with abundant bacterial growth, most fish had one $(43.3 \%)$ or $2(40.8 \%)$ bacterial species, and a small proportion had $3(9.2 \%)$ or 4 or more $(6.3 \%)$ species. Vibrio harveyi accounted for $31 \%$ of the bacterial species recovered as single isolates,

Table 3. Sparus aurata. Percentage of diseased gilthead sea bream (with clinical signs) among fish with different amounts of bacterial growth, from the different types of facilities and studies. A statistically significant relationship was found between the bacterial growth $(0=$ no growth, $\mathrm{T}=$ traces of growth, $\mathrm{A}=$ abundant growth $)$ and the presence of disease signs at ${ }^{*} \mathrm{p}<0.0001$ or ${ }^{* *} \mathrm{p}<0.05$. IATS: Instituto de Acuicultura de Torre de la Sal

\begin{tabular}{|c|c|c|c|c|c|c|c|}
\hline \multirow{3}{*}{ Bacterial growth } & \multirow{2}{*}{\multicolumn{2}{|c|}{$\begin{array}{c}\text { Study B - } \\
- \text { Type of facilities }-\end{array}$}} & \multirow{3}{*}{ Total $^{* *}$} & \multirow{2}{*}{\multicolumn{3}{|c|}{$\begin{array}{c}\text { Study } \mathrm{C} \\
\text { Type of facilities }\end{array}$}} & \multirow{3}{*}{ Total $^{* *}$} \\
\hline & & & & & & & \\
\hline & $\begin{array}{l}\text { Sea cages } \\
(\mathrm{F} 1+\mathrm{F} 2)\end{array}$ & $\begin{array}{l}\text { Earth ponds* } \\
\text { (F3) }\end{array}$ & & $\begin{array}{l}\text { Sea cages* } \\
(\mathrm{F} 1+\mathrm{F} 2+\mathrm{F} 4)\end{array}$ & $\begin{array}{l}\text { Earth ponds } \\
\text { (F3) }\end{array}$ & IATS & \\
\hline 0 & 13.5 & 5.6 & 9.1 & 23.1 & 0 & 36.4 & 23.2 \\
\hline $\mathrm{T}$ & 25.3 & 7.7 & 18.7 & 33.3 & 0 & 100 & 32.6 \\
\hline A & 30.4 & 44.7 & 36.2 & 62.9 & 66.7 & 90 & 68.8 \\
\hline
\end{tabular}

Table 4. Sparus aurata. Percentages of the positive gilthead sea bream yielding each bacterial species in Studies B and C, and their distribution according to the presence of clinical signs and the season. Of the Gram-positives, none was a lactic acid bacteria (LAB). As $60 \%$ of the individuals carried more than 1 species, percentages are not cumulative. $\mathrm{N}=$ number of positive fish in each category

\begin{tabular}{|c|c|c|c|c|c|}
\hline \multirow[t]{2}{*}{ Species isolated } & \multirow{2}{*}{$\begin{array}{c}\text { Total } \\
(\mathrm{n}=320)\end{array}$} & \multicolumn{2}{|c|}{ - Clinical signs $\_$} & \multicolumn{2}{|c|}{ Season } \\
\hline & & $\begin{array}{c}\text { With } \\
(\mathrm{n}=111)\end{array}$ & $\begin{array}{l}\text { Without } \\
(\mathrm{n}=209)\end{array}$ & $\begin{array}{l}\text { December-May } \\
\quad(\mathrm{n}=160)\end{array}$ & $\begin{array}{c}\text { June-November } \\
\qquad(\mathrm{n}=160)\end{array}$ \\
\hline Vibrio alginolyticus & 3.1 & 2.7 & 3.3 & 0 & 6.3 \\
\hline Vibrio fisheri & 8.1 & 6.3 & 9.1 & 15.0 & 1.3 \\
\hline Vibrio harveyi & 24.4 & 27.0 & 22.9 & 5.0 & 43.8 \\
\hline Vibrio ichthyoenteri-like & 12.2 & 1.8 & 17.7 & 11.9 & 12.5 \\
\hline Vibrio mediterranei & 0.3 & 0.9 & 0 & 0 & 0.6 \\
\hline Vibrio pelagius & 1.3 & 0.9 & 1.4 & 0 & 2.5 \\
\hline Vibrio splendidus & 14.4 & 15.3 & 13.9 & 28.8 & 0 \\
\hline Vibrio tubiashii & 1.6 & 0 & 2.4 & 0.6 & 2.5 \\
\hline Vibrio sp. LB+ & 5.3 & 7.2 & 4.3 & 2.5 & 8.1 \\
\hline Other unidentified Vibrio spp. & 7.2 & 6.3 & 7.7 & 6.9 & 8.8 \\
\hline Ph. damselae ssp. damselae & 11.6 & 11.7 & 11.5 & 7.5 & 15.6 \\
\hline Alteromonas macleodii & 1.6 & 0 & 2.4 & 0 & 3.1 \\
\hline Cytophaga/Flavobacterium & 10.0 & 15.3 & 7.2 & 13.8 & 6.3 \\
\hline Marinomonas spp. & 3.8 & 0.9 & 5.3 & 6.3 & 1.3 \\
\hline Pseudoalteromonas espejiana & 5.0 & 0 & 7.7 & 3.4 & 6.3 \\
\hline Pseudoalteromonas haloplanktis & 6.6 & $11.7^{\mathrm{a}}$ & 3.8 & 11.3 & 1.9 \\
\hline Pseudoalteromonas spp. & 6.6 & 0.9 & 3.3 & 4.4 & 8.8 \\
\hline Pseudoalteromonas undina & 2.5 & 2.7 & 8.6 & 3.1 & 1.9 \\
\hline Shewanella spp. & 1.9 & 1.8 & 1.9 & 3.1 & 0.6 \\
\hline Gram-positives & 2.8 & 0 & 4.3 & 3.4 & 1.9 \\
\hline
\end{tabular}




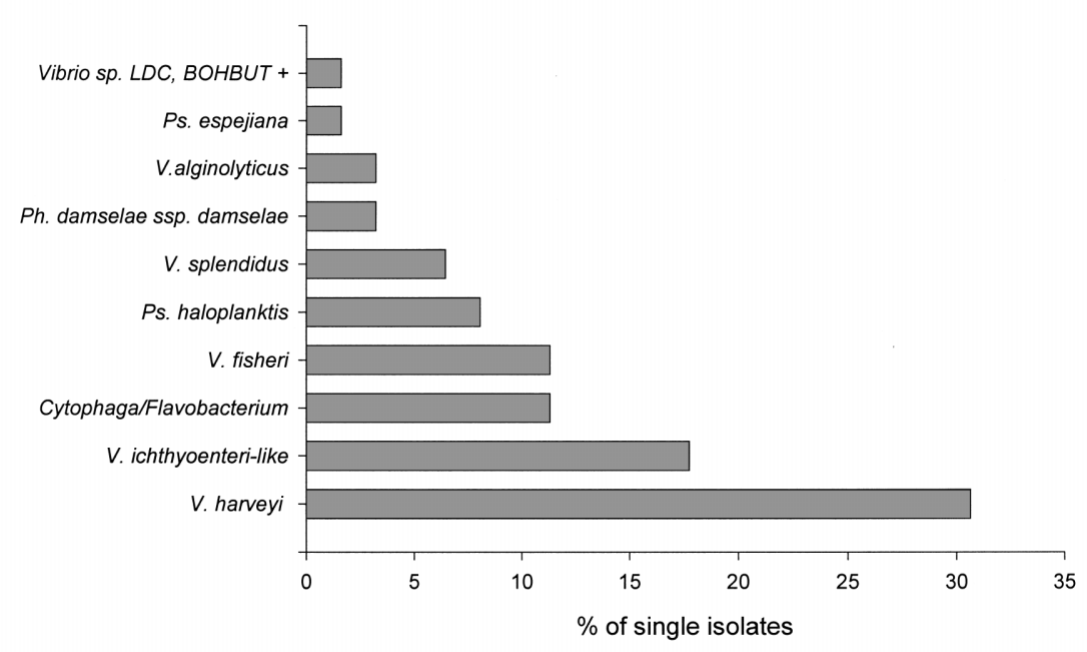

Fig. 1. Sparus aurata. Percentage of each of bacterial species among pure isolates obtained from gilthead sea bream analysed in Studies B and C

percentage of fish examined in routine samplings (almost $60 \%$ ) yielded bacterial growth, although few of them showed disease signs. The significantly higher percentage of diseased fish in Study C was expected due to the particular pattern of the samplings performed. Similar percentages of infected individuals were obtained by Baptista et al. (1999) for diseased fish. However, in the present study, bacterial growth was found to be dependent on the type of facility, with fish from sea cages showing the highest percentages of bacterial infection.

In both Studies B and C, Vibrio spp. were the dominant bacteria, although oxidative species such as Cytophaga/ Flavobacterium and Pseudoaltero-

whereas Photobacterium damselae ssp. damselae represented less than $5 \%$ of single isolates. Both species accounted for $30 \%$ of the individuals carrying 2 species (Fig. 1).

\section{DISCUSSION}

In Study A, bacterial diversity was higher in water samples than in larval homogenates, but most bacterial species found in the larvae were also present in the water. The dominant bacteria found in the water were also found in previous analyses of the same area (Ortigosa et al. 1994a,b, Arias et al. 1999, Pujalte et al. 1999). The only study specifically devoted to the analysis of the bacterial content of Sparus aurata larvae, performed by Grisez et al. (1997), found no dominant or persistent colonisation of the intestines of the larvae up to $30 \mathrm{~d}$, and reported that fluctuations in the composition of the dominant microflora were closely related to the bacterial contents of the ingested food. Our data are not comparable due to the fact that we have studied older larvae, but we have observed a drastic change in dominant bacterial species after weaning with an unexpected dominance of oxidative species in 60 d old larvae. Larvae from other fish species, Paralichthys dentatus, have been recently shown to undergo a similar reduction of the ratio Vibrio spp.: total heterotrophs on the intestinal content between the Stage-2 larvae and the after-weaning juveniles (Eddy \& Jones 2002).

In growing fish, the work focussed on cases of disease outbreaks or abnormal events (Study C), and also on routine periodic samplings (Study B), and in both studies samples might have included diseased and asymptomatic fish. Our results revealed that a high monas spp. were also abundant. V. harveyi was the species most frequently recovered from fish in both studies in all the culture systems. This species has been increasingly reported in association with infectious outbreaks in different marine organisms, including gilthead sea bream, common dentex and European sea bass (Saeed 1995, Alvarez et al. 1998, Balebona et al. 1998b, Company et al. 1999, Zhang \& Austin 2000, Alcaide et al. 2001). Its role as primary pathogen for gilthead sea bream has been claimed by Balebona et al. (1998b), who found it virulent for juvenile gilthead sea bream. In our study, one out of 4 fish yielding any bacterial growth and one out of 3 fish yielding abundant growth carried $V$. harveyi. However, less than $50 \%$ of the individuals yielding abundant growth of this species showed clinical signs. Since $V$. harveyi is the dominant Vibrio sp. in water and bivalves from the same Mediterranean area above $20^{\circ} \mathrm{C}$ (Arias et al. 1999, Pujalte el al. 1999), we should disregard it as a primary pathogen; otherwise fish populations would be decimated in a few weeks. Thus, this species could act as an opportunistic pathogen and/or its pathogenicity might be restricted to a limited number of $V$. harveyi strains. In support of these views, we can point out the low proportion of fish carrying this species that show clinical signs, and also the absence of mortality in experimental infections of gilthead sea bream with $V$. harveyi strains recovered from the diseased individuals of this study (Pujalte et al. 2003).

Vibrio splendidus was present in ca. $15 \%$ of all fish yielding bacterial growth, and in $15 \%$ of diseased fish. However, nearly $70 \%$ of the fish carrying this species and yielding abundant growth showed clinical signs, which strongly suggests some role in pathogenicity. This species has been associated with disease outbreaks in several types of aquatic organisms, including 
gilthead sea bream and turbot larvae (Sedano et al. 1996, Gatesoupe et al. 1999). Balebona et al. (1998b) considered it a 'primary' pathogen. Notwithstanding this, the actual role of $V$. splendidus in pathogenicity is still unclear, in part due to the problems of its differentiation from other species. In our study, this species was recovered only during the cold season, when it was present in 1 out of every 3 carrier fish.

Several Vibrio spp. previously recorded as opportunistic pathogens for different aquatic animals were also identified during the study. $V$. alginolyticus was detected in low percentages (around $3 \%$ ) in all groups, yet only in the warm season. Its role in pathogenicity for gilthead sea bream seems to be restricted to animals with damaged skin (Balebona et al. 1998a). $V$. fisheri, mainly isolated in winter, was more frequent $(8.1 \%)$ than $V$. alginolyticus. Previous findings indicate an association with larval diseases (Sedano et al. 1996), and $\mathrm{LD}_{50}$ of $10^{5}$ to $10^{7} \mathrm{cfu} \mathrm{g}^{-1}$ for juvenile Sparus aurata (Babelona et al. 1998b).

Using phenotypic characteristics, several strains, identified as Vibrio ichthyoenteri-like, constituted the third most abundant Vibrio sp. Although V. ichthyoenteri was originally described as pathogenic for Japanese flounder larvae (Ishimaru et al. 1996), our isolates were very infrequent in fish with clinical signs, and were clearly associated with asymptomatic individuals during the whole year. Whether these facts could be related to a protective or beneficial role against infection by other bacteria, as suggested for other Vibrio spp. (Huys et al. 2001), needs further confirmation.

A relatively low percentage of fish carried a Vibrio sp. LB+ (lysine decarboxylase and $\beta$-hydroxybutyrate+), different from all the known Vibrio spp. Its main characteristics are the presence of lysine decarboxylase and growth on $\beta$-hydroxybutyrate. This species was very frequent in diseased fish from the IATS facilities, together with $V$. harveyi and Photobacterium damselae ssp. damselae.

Photobacterium damselae ssp. damselae, a classical fish pathogen less frequently reported than $P$. damselae ssp. piscicida from gilthead sea bream, showed moderate occurrence in our study. Although the isolation percentages as single species were low, these values increased considerably when it was associated with $V$. harveyi, which could suggest some synergetic infectious or colonising effect.

In the current study, the absence of typical fish pathogens among the fermentative bacteria, such as Photobacterium damselae ssp. piscicida, Vibrio anguillarum and $V$. ordalii, frequently reported in association with disease outbreaks for cultured gilthead sea bream (Toranzo et al. 1991, 1997, Rodger \& Furones 1998) was noteworthy. Such absence could be explained by the age of the fish routinely sampled, the wide use of vaccination and/or their presence in low numbers, undetectable by cultural methods.

Cytophaga/Flavobacterium have been increasingly associated with mortalities in farmed fish (Pazos et al. 1993, Bernardet et al. 1994, Chen et al. 1995). In our study, this group was more abundant in our fish during the cold season. A total of $74 \%$ of fish with both abundant growth and Cytophaga/Flavobacterium group had clinical signs, which strongly suggests a pathogenic effect. The specific identity of the isolates was not clear, but none of them corresponded to the classical pathogen Flexibacter maritimus. Pseudoalteromonas haloplanktis was mainly isolated in one spring sampling associated to a disease outbreak. None of our strains corresponded to Pseudomonas anguilliseptica, isolated in Spain and Portugal in recent years, and associated with the 'winter disease' (Berthe et al. 1995, Domenech et al. 1997). Gram-positive bacteria recorded as pathogenic for fish, mainly members of the lactic acid bacteria, were absent among the isolates recovered from the fish analysed.

In conclusion, the species identified in the current study correspond to normal inhabitants of marine environments that can act as emergent or opportunistic pathogens for cultured fish. It is remarkable that most of them were present in both diseased and asymptomatic fish, the only exception being the Vibrio ichthyoenteri-like isolate. The exact role of each species in pathogenicity has to be elucidated through experimental infections, although the frequent recovery of 2 or more species from the same individual could suggest the participation of more than 1 species in the infectious status.

Acknowledgements. This work was supported by research grants from the Spanish Ministerio de Educación, Cultura y Deporte MAR98-1000-C02-02 and FEDER Program 1FD97979-C02. We are thankful to M. L. Alonso for technical assistance in the samplings.

\section{LITERATURE CITED}

Alcaide E, Gil-Sanz C, Sanjuan E, Esteve D, Amaro C, Silveira L (2001) Vibrio harveyi causes disease in seahorse, Hippocampus sp. J Fish Dis 24:311-313

Álvarez DJ, Austin B, Álvarez AM, Reyes H (1998) Vibrio harveyi: a pathogen of penaeid shrimps and fish in Venezuela. J Fish Dis 21:313-316

Arias CR, Macián MC, Aznar R, Garay E, Pujalte MJ (1999) Low incidence of Vibrio vulnificus among Vibrio isolates from seawater and shellfish of the western Mediterranean coast. J Appl Microbiol 86:125-134

Balebona MC, Moriñigo MA, Faris A, Krovacek K, Mansson I, Bordas MA, Borrego JJ (1995) Influence of salinity and $\mathrm{pH}$ on the adhesion of pathogenic Vibrio strains to Sparus aurata skin mucus. Aquaculture 132:113-120

Balebona MC, Andreu MJ, Bordas MA, Zorrilla I, Moriñigo MA, Borrego JJ (1998a) Pathogenicity of Vibrio alginolyti- 
cus for cultured gilt-head sea bream (Sparus aurata L.). Appl Environ Microbiol 64:4269-4275

Balebona M, Zorrilla I, Moriñigo MA, Borrego JJ (1998b) Survey of bacterial pathologies affecting farmed gilt-head sea bream (Sparus aurata L.) in southwestern Spain from 1990 to 1996. Aquaculture 166:19-35

Balows A, Trüper HG, Dworkin MD, Harder W, Schleifer KH (1992) The Prokaryotes, 2nd edn. Springer-Verlag, New York

Baptista T, Costa J, Soares F (1999) Patologías más comunes en dorada (Sparus aurata) y lubina (Dicentrarchus labrax) registradas en las piscifactorias al sur del río Tajo durante 1998. AquaTIC art. 702, UNIZAR (Universidad de Zaragosa)

Bernardet JF, Kerouault B, Michel C (1994) Comparative study on Flexibacter maritimus strains isolated from farmed sea bass (Dicentrarchus labrax) in France. Fish Pathol 29:105-111

Berthe FCJ, Michel C, Bernardet JF (1995) Identification of Pseudomonas anguilliseptica isolated from several fish species in France. Dis Aquat Org 21:151-155

Bovo G, Borghesan P, Comuzzi M, Ceshia G, Giorgetti G (1995) 'Winter disease' in reared sea bream: preliminary observations. 3rd Natl Conf Italian Soc Fish Path 7:2-11

Breuil G, Haffner P (1990) A field report on vibrio disease of sea bass (Dicentrarchus labrax) in the south of France. Adv Trop Aquac 9:161-169

Chen MF, Henry-Ford D, Groff D (1995) Isolation and characterization of Flexibacter maritimus from marine fishes of California. J Aquat Anim Health 7:318-326

Company R, Sitjà-Bobadilla A, Pujalte MJ, Garay E, AlvarezPellitero P, Pérez-Sánchez J (1999) Bacterial and parasitic pathogens in cultured common dentex, Dentex dentex L. J Fish Dis 22:299-309

Domenech A, Fernández-Garayzábal J, Lawson P, García JA and 6 others (1997) Winter disease outbreak in sea-bream (Sparus aurata) associated with Pseudomonas anguilliseptica infection. Aquaculture 156:317-326

Eddy SD, Jones SH (2002) Microbiology of summer flounder Paralichthys dentatus fingerling production at a marine fish hatchery. Aquaculture 211:9-28

Gatesoupe FJ, Lambert C, Nicolas JL (1999) Pathogenicity of Vibrio splendidus strains associated with turbot larvae, Scophthalmus maximus. J Appl Microbiol 87:757-763

Grisez L, Reyniers J, Verdonck L, Swings J, Ollevier F (1997) Dominant intestinal microflora of sea bream and sea bass larvae, from two hatcheries, during larval development. Aquaculture 155:387-399

Holt JG, Krieg NR, Sneath PHA, Staley JT, Williams ST (1994) Bergey's manual of determinative bacteriology, 9th edn. Williams \& Wilkins, Baltimore

Huys L, Dhert P, Robles R, Ollevier F, Sorgeloos P, Swings J

Editorial responsibility: David Bruno,

Aberdeen, Scotland, UK
(2001) Search for benefical bacterial strains for turbot (Scophthalmus maximus L.) larviculture. Aquaculture 193: 25-37

Ishimaru K, Akagawa-Matsushita M, Muroga K (1996) Vibrio ichthyoenteri sp. nov., a pathogen of Japanese flounder (Paralichthys olivaceus) larvae. Int J Syst Bacteriol 46: 155-159

Ortigosa M, Garay E, Pujalte MJ (1994a) Numerical taxonomy of Vibrionaceae isolated from oysters and seawater along an annual cycle. Syst Appl Microbiol 17:216-225

Ortigosa M, Garay E, Pujalte MJ (1994b) Numerical taxonomy of aerobic, Gram-negative bacteria associated with oysters and surronding seawater of the Mediterranean coast. Syst Appl Microbiol 17:589-600

Pazos F, Santos Y, Núñez S, Toranzo AE (1993) Increasing occurrence of Flexibacter maritimus in the marine aquaculture of Spain. Am Fish Soc, Fish Health Section Newsl 21:1-2

Pujalte MJ, Ortigosa M, Macián MC, Garay E (1999) Aerobic and facultative anaerobic heterotrophic bacteria associated to Mediterranean oysters and seawater. Int Microbiol 2:259-266

Pujalte MJ, Sitja-Bobadilla A, Macián MC, Belloch C, Alvarez-Pellitero $P$, Pèrez-Sánchez J, Uruburu F, Garay E (2003) Virulence and molecular typing of Vibrio harveyi strains isolated from cultured dentex, gilthead sea bream and European sea bass. Syst Appl Microbiol (in press)

Rodgers CJ, Furones MD (1998) Disease problems in cultured marine fish in the Mediterranean. Fish Pathol 33:157-164

Saeed MO (1995) Association of Vibrio harveyi with mortalities in cultured marine fish in Kuwait. Aquaculture 136: $21-29$

Sedano J, Zorrilla I, Moriñigo MA, Balebona MC, Vidaurreta A, Bordas MA, Borrego JJ (1996) Microbial origin of the abdominal swelling affecting farmed larvae of gilt-head sea bream, Sparus aurata L. Aquac Res 27:323-333

Sokal RR, Rohlf FJ (1981) Biometry, 2nd edn. WH Freeman, New York

Toranzo AE, Barreiro S, Casal JF, Figueras A, Magariños B, Barja JL (1991) Pasteurellosis in cultured gilthead sea bream (Sparus aurata): first report in Spain. Aquaculture 99:1-15

Toranzo AE, Dopazo C, Romalde JL, Santos Y, Barja JL (1997) Estado actual de la patología bacteriana y vírica en la piscicultura española. AquaTIC art. 105, UNIZAR (Universidad de Zaragosa)

Vera P, Navas JI, Fouz B (1991) First isolation of $V$. damsela from sea bream (Sparus aurata). Bull Eur Assoc Fish Pathol 11:112-113

Zhang XH, Austin B (2000) Pathogenicity of Vibrio harveyi to salmonids. J Fish Dis 23:93-102

Submitted: May 28, 2002; Accepted: November 7, 2002

Proofs received from author(s): March 6, 2003 